Acta Crystallographica Section B

Structural Science, Crystal Engineering and Materials

ISSN 2052-5206

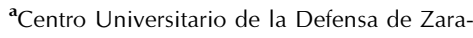
goza, Ctra Huesca s/n, Zaragoza, 50090 Zaragoza, Spain, ${ }^{\mathbf{b}}$ Instituto de Ciencia de Materiales de Aragón, CSIC-Universidad de Zaragoza, C/Pedro Cerbuna 12, Zaragoza, 50009 Zaragoza, Spain, 'Institut Laue Langevin, 6 rue Jules Horowitz, BP 156, 38000 Grenoble, France, ${ }^{\mathbf{d}}$ Laboratorio de Rayos $\mathrm{X}$ y Materiales Moleculares, Departamento de Física Fundamental II, Facultad de Física, Universidad de La Laguna, Avda Astrofísico Francisco Sánchez s/n, La Laguna, 38204 Tenerife, Spain, and ${ }^{\mathbf{e}}$ Instituto de Productos Naturales y agrobiología (CSIC), Instituto Universitario de Bioorgánica 'Antonio González', Universidad de La Laguna, Avda Astrofísico Francisco Sánchez s/n, La Laguna, 38204 Tenerife, Spain

Correspondence e-mail: lauracd@unizar.es, caruiz@ull.es

\title{
Three new europium(III) methanetriacetate metal- organic frameworks: the influence of synthesis on the product topology
}

Three new metal-organic framework structures containing $\mathrm{Eu}^{\text {III }}$ and the little explored methanetriacetate $\left(\mathrm{C}_{7} \mathrm{H}_{7} \mathrm{O}_{6}{ }^{3-}\right.$, $\mathrm{mta}^{3-}$ ) ligand have been synthesized. Gel synthesis yields a two-dimensional framework with the formula [ $\mathrm{Eu}(\mathrm{mta})$ $\left.\left(\mathrm{H}_{2} \mathrm{O}\right)_{3}\right]_{n} \cdot 2 n \mathrm{H}_{2} \mathrm{O}$, (I), while two polymorphs of the threedimensional framework material $\left[\mathrm{Eu}(\mathrm{mta})\left(\mathrm{H}_{2} \mathrm{O}\right)\right]_{n} \cdot n \mathrm{H}_{2} \mathrm{O}$, (II) and (III), are obtained through hydrothermal synthesis at either 423 or $443 \mathrm{~K}$. Compounds (I) and (II) are isomorphous with previously reported $\mathrm{Gd}^{\mathrm{III}}$ compounds, but compound (III) constitutes a new phase. Compound (I) can be described in terms of dinuclear $\left[\mathrm{Eu}_{2}\left(\mathrm{H}_{2} \mathrm{O}\right)_{4}\right]^{6+}$ units bonded through $\mathrm{mta}^{3-}$ ligands to form a two-dimensional framework with topology corresponding to a $(6,3)$-connected binodal $\left(4^{3}\right)\left(4^{6} 6^{6} 8^{3}\right)$-kgd net, where the dinuclear $\left[\mathrm{Eu}_{2}\left(\mathrm{H}_{2} \mathrm{O}\right)_{4}\right]^{6+}$ units are considered as a single node. Compounds (II) and (III) have distinct three-dimensional topologies, namely a $\left(4^{12} 6^{3}\right)\left(4^{9} 6^{6}\right)$-nia net for (II) and a $\left(4^{10} 6^{5}\right)\left(4^{11} 6^{4}\right)-\mathbf{K}_{2} \mathbf{O}_{2} ; 36641$ net for (III). The crystal density of (III) is greater than that of (II), consistent with the increase of temperature, and thereby autogeneous pressure, in the hydrothermal synthesis.

\section{Introduction}

The construction of metal-organic frameworks (MOFs) based on different self-assembly synthetic routes is a fruitful strategy to obtain new polymorphic systems (Furukawa et al., 2013; Kitagawa et al., 2004; Tian et al., 2007; Yaghi et al., 2003). Three important aspects should be taken into account in the selfassembly strategy: (a) utilization of organic ligands with well characterized coordination modes, which act as linkers; $(b)$ selection of metal ions with a desirable coordination geometry, acting as nodes in the framework; (c) control of the various interactions between the linkers and nodes (covalent, hydrogen bonds, van der Waals etc.), in order to generate a particular topology in the MOF product. Assembly of organic linkers with inorganic nodes opens a huge number of possibilities in crystal engineering, where the resulting MOFs show interesting properties that are strongly influenced by their topology. These compounds have attracted the attention of researchers for many different applications, such as gas storage, catalysis or magnetism (for example Li et al., 2011; Wang, Zhang, Liu et al., 2007; Sumida et al., 2012; Zhang et al., 2011; Lee et al., 2009; Farha et al., 2010; Cañadillas-Delgado et al., 2012).

The appropriate selection of the organic linker together with a rational synthetic route can be used to modulate structural diversity. Among the different organic ligands, those containing carboxylate groups are often selected due to their abundant coordination modes, which allow the occurrence of
Received 26 July 2013

Accepted 23 December 2013 
Table 1

Experimental details.

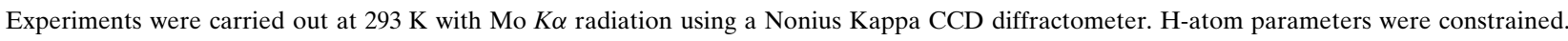

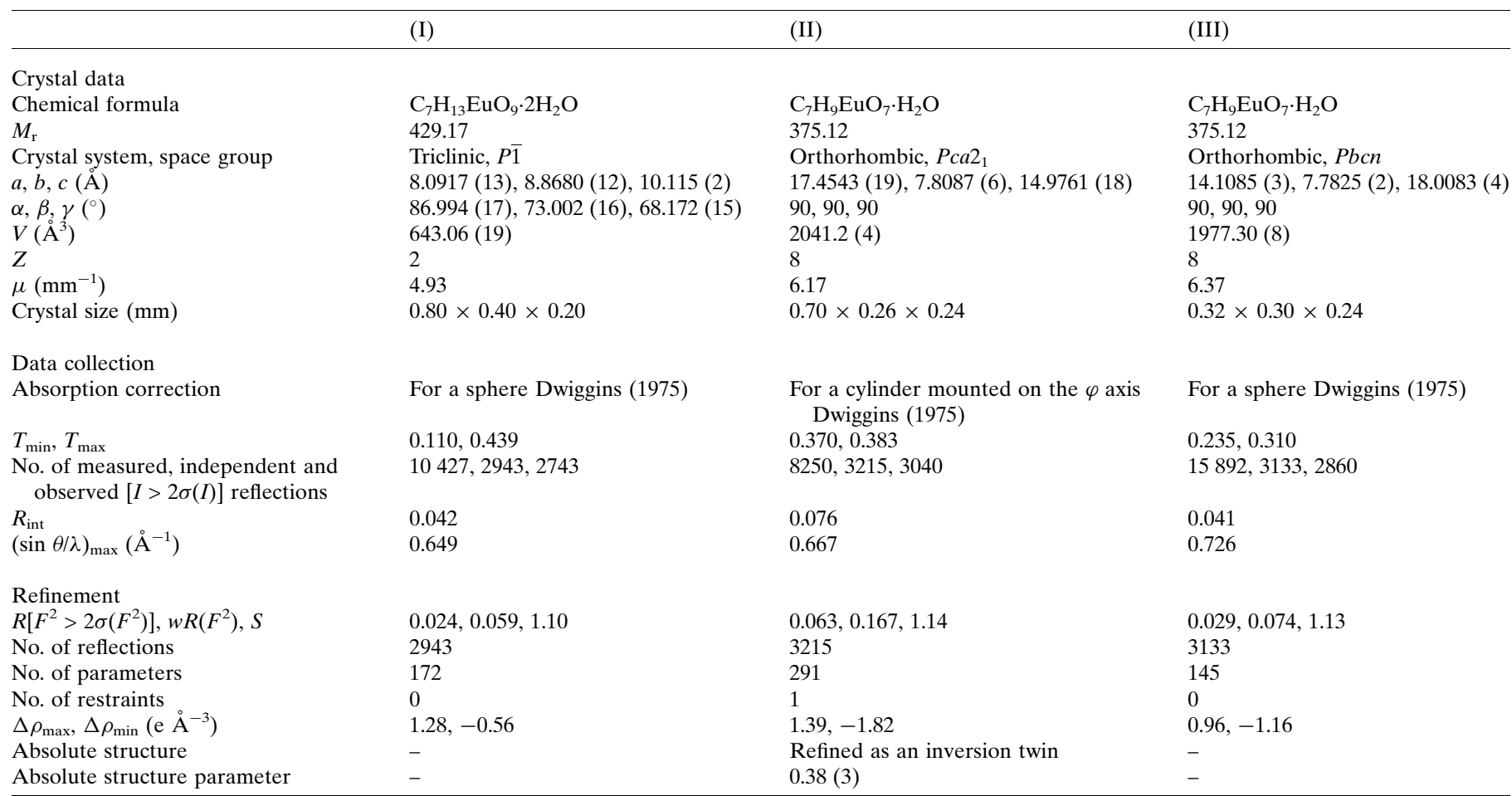

Computer programs: COLLECT (Nonius, 1998), EVALCCD (Duisenberg et al., 2003), HKL2000 (Otwinowski \& Minor, 1997), SHELXS97, SHELXL97 (Sheldrick, 2008), DIAMOND (Brandenburg, 1999), WinGX (Farrugia, 1999), PARST95 (Nardelli, 1995) and PLATON (Spek, 2009).

different structural topologies, together with the ability of the carboxylate group to act as a hydrogen-bond acceptor and/or donor, which can help to stabilize the crystal structure. Moreover, carboxylate groups are hard Lewis bases with a remarkable ability to bind strongly to lanthanide ions. In order to tune the topology of new MOFs, it would be useful to exploit organic building blocks with a desirable symmetry, in order to attempt to reproduce that symmetry in the generated framework structure. We have explored the use of tripodal carboxylate ligands, of which the rigid 1,3,5-benzenetricarboxylic acid (btc) is one of the most highly represented in the literature (Chen et al., 2007; Gao et al., 2006; Gustafsson et al., 2008). Among btc-lanthanide complexes, one of the better characterized corresponds to MOF-76, where $\mathrm{Ln}^{\mathrm{III}}$ binds to six different btc ligands, and each btc ligand binds to six different $\mathrm{Ln}^{\mathrm{III}}$ ions, giving rise to a chiral three-dimensional framework with square-shaped channels (Rosi et al., 2005). The conformational freedom of flexible ligands may provide an extra possibility for the construction of unprecedented topologies, as in the case of propane-1,2,3-tricarboxylic acid (tricarballylic acid, $\mathrm{H}_{3}$ tca; Cañadillas-Delgado et al., 2008), where the ligand adopts a T-shaped conformation that promotes (6,3)-type networks with 'brickwall' or 'herringbone' morphologies. In an effort to obtain systems with higher symmetry, we have explored methanetriacetic acid (hereafter denoted $\mathrm{H}_{3} \mathrm{mta}$ ), which represents a $C_{3}$-symmetric scaffold that can promote hexagonal topologies in the final framework structure.

Our selection of lanthanide ions as nodes for the preparation of new framework structures is based on their relatively large ionic radii, which give rise to large coordination numbers. In the particular case of $\mathrm{Eu}^{\mathrm{III}}$, the most common coordination number is nine, mostly with distorted tricapped trigonal prismatic or monocapped square antiprismatic geometry. Coordination numbers of eight or ten are less common, although they are quite well represented in the literature, in contrast to coordination numbers of six or seven, which are scarce. Therefore, the selection of $\mathrm{Eu}^{\mathrm{III}}$ to act as a framework node promotes the occurrence of high-dimensional systems with unusual network topologies.

In this paper we report three new metal-organic frameworks containing $\mathrm{Eu}^{\text {III }}$ and the $\mathrm{mta}^{3-}$ ligand. Two of them, $\left[\mathrm{Eu}(\mathrm{mta})\left(\mathrm{H}_{2} \mathrm{O}\right)_{3}\right]_{n} \cdot 2 n \mathrm{H}_{2} \mathrm{O}$ (I) and $\left[\mathrm{Eu}(\mathrm{mta})\left(\mathrm{H}_{2} \mathrm{O}\right)\right]_{n} \cdot n \mathrm{H}_{2} \mathrm{O}$ (II), are isomorphous with known $\mathrm{Gd}^{\mathrm{III}}$ compounds (Cañadillas-Delgado et al., 2010), while the third, [Eu(mta)$\left.\left(\mathrm{H}_{2} \mathrm{O}\right)\right]_{n} \cdot n \mathrm{H}_{2} \mathrm{O}$ (III), is a polymorph of (II) and is a new phase. The three compounds have been obtained using either gel synthesis [for (I)] or hydrothermal methods [for (II) and (III)]. Polymorphs (II) and (III) are obtained by varying the temperature, and consequently the autogenous pressure, of the hydrothermal synthesis. 
Table 2

Selected distances $(\AA)$ and angles $\left(^{\circ}\right)$ for (I), (II) and (III).

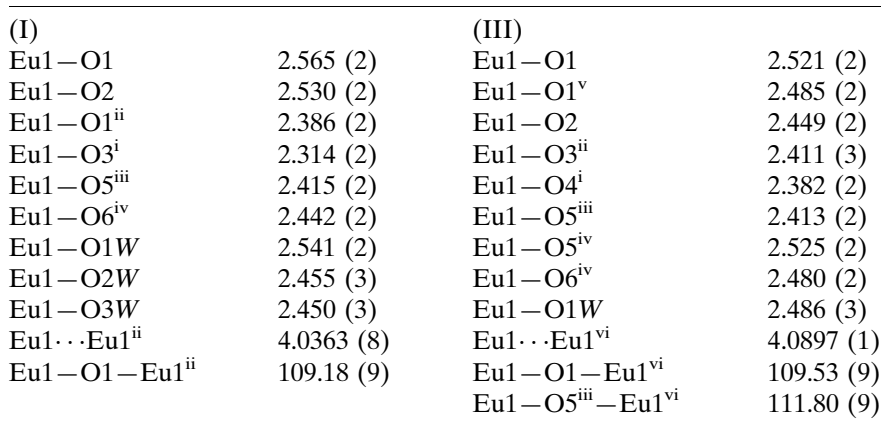

\begin{tabular}{|c|c|c|c|}
\hline \multicolumn{4}{|l|}{ (II) } \\
\hline Eu1-O1 & $2.431(7)$ & $\mathrm{Eu} 2-\mathrm{O} 1$ & $2.502(7)$ \\
\hline $\mathrm{Eu} 1-\mathrm{O} 3^{\mathrm{i}}$ & $2.307(6)$ & $\mathrm{Eu} 2-\mathrm{O} 2$ & $2.445(7)$ \\
\hline $\mathrm{Eu} 1-\mathrm{O} 5^{\mathrm{ii}}$ & $2.445(6)$ & $\mathrm{Eu} 2-\mathrm{O} 4^{\mathrm{i}}$ & $2.435(9)$ \\
\hline $\mathrm{Eu} 1-\mathrm{O} 7$ & $2.480(6)$ & $\mathrm{Eu} 2-\mathrm{O}{ }^{\mathrm{ii}}$ & $2.499(7)$ \\
\hline Eu1-O8 & $2.520(6)$ & $\mathrm{Eu} 2-\mathrm{O} 6^{\mathrm{ii}}$ & $2.480(7)$ \\
\hline Eu1-O10 & $2.462(8)$ & $\mathrm{Eu} 2-\mathrm{O}^{\mathrm{vi}}$ & $2.472(6)$ \\
\hline $\mathrm{Eu} 1-\mathrm{O} 11^{\mathrm{i}}$ & $2.521(7)$ & $\mathrm{Eu} 2-\mathrm{O} 9^{\mathrm{iv}}$ & $2.319(6)$ \\
\hline $\mathrm{Eu} 1-\mathrm{O} 12^{\mathrm{i}}$ & $2.488(6)$ & $\mathrm{Eu} 2-\mathrm{O} 12^{\mathrm{v}}$ & $2.443(7)$ \\
\hline $\mathrm{Eu} 1-\mathrm{O} 1 W$ & $2.526(7)$ & $\mathrm{Eu} 2-\mathrm{O} 2 W$ & 2.495 (7) \\
\hline Eu1 $\cdots$ Eu2 & $4.0767(5)$ & $\mathrm{Eu} 2 \cdots \mathrm{Eu}^{\mathrm{vi}}$ & $4.0767(5)$ \\
\hline Eu1-O1-Eu2 & $111.5(3)$ & $\mathrm{Eu} 2-\mathrm{O} 8^{\mathrm{vi}}-\mathrm{Eu} 1^{\mathrm{vi}}$ & $109.5(2)$ \\
\hline $\mathrm{Eu} 1-\mathrm{O} 5^{\mathrm{ii}}-\mathrm{Eu} 2$ & $111.2(2)$ & $\mathrm{Eu} 2-\mathrm{O} 12^{\mathrm{v}}-\mathrm{Eu} 1^{\mathrm{vi}}$ & $111.5(3)$ \\
\hline
\end{tabular}

Symmetry codes for (I): (i) $-x,-y+2,-z$; (ii) $-x,-y+1,-z$; (iii) $x-1, y, z$; (iv) $-x+1,-y+1,-z$. Symmetry codes for (II): (i) $-x+\frac{1}{2}, y, z-\frac{1}{2}$; (ii) $-x,-y, z-\frac{1}{2}$; (iii) $x-\frac{1}{2},-y+1, z$; (iv) $x-\frac{1}{2},-y, z ;$ (v) $-x+\frac{1}{2}, y-1, z-\frac{1}{2}$; (vi) $x, y-1$, $z$. Symmetry codes for (III): (i) $-x+1, y,-z-\frac{1}{2}$; (ii) $x+\frac{1}{2}, y-\frac{1}{2},-z-\frac{1}{2}$; (iii) $-x+\frac{3}{2},-y+\frac{3}{2}, z-\frac{1}{2}$; (iv) $x,-y+1, z-\frac{1}{2} ;$ (v) $-x+\frac{3}{2}, y-\frac{1}{2}, z$; (vi) $-x+\frac{3}{2}, y+\frac{1}{2}, z$.

\section{Experimental}

\subsection{Synthesis}

Methanetriacetic acid $\left(\mathrm{H}_{3} \mathrm{mta}\right)$ was prepared and characterized following reported methods (Baumeister et al., 2002; Gupta et al., 1987; Cañadillas-Delgado et al., 2010). The other reagents and solvents were purchased from commercial sources and used as received. X-ray quality crystals of (I) were grown by slow diffusion within a gel medium following the technique described by Henisch (1970), whereas those of (II) and (III) were obtained through hydrothermal synthesis (Byrappa \& Yoshimura, 2001). Elemental analyses (C, H) were performed on an EA1108 CHNS-O microanalytical instrument.

2.1.1. [ $\left.\mathrm{Eu}(\mathbf{m t a})\left(\mathrm{H}_{\mathbf{2}} \mathrm{O}\right)_{3}\right]_{\boldsymbol{n}} \cdot \mathbf{2} \mathbf{n} \mathrm{H}_{\mathbf{2}} \mathrm{O}$ (I). The $\mathrm{pH}$ of an $0.07 \mathrm{M}$ aqueous solution of methanetriacetic acid $\left(3 \mathrm{ml} \mathrm{H}_{2} \mathrm{O}\right.$ and $4 \mathrm{ml}$ of ethanol) was adjusted to 4.5 by adding an aqueous solution of $\mathrm{NaOH}$. Afterwards, $0.7 \mathrm{ml}$ of tetramethoxysilane was added to the resulting solution. The mixture was introduced into a test tube, covered and stored for $1 \mathrm{~d}$ at room temperature to allow the formation of a gel. Finally, an aqueous solution of $\mathrm{Eu}\left(\mathrm{NO}_{3}\right)_{3} \cdot 6 \mathrm{H}_{2} \mathrm{O}(0.1 \mathrm{M}, 2.5 \mathrm{ml})$ was placed on the gel, with care being taken to avoid damaging the gel surface, and the tubes were stored at $303 \mathrm{~K}$. Colourless needle-like crystals of (I) appeared after a few days. The yield at that moment was $c a$ $40 \%$. Anal.: calc. for $\mathrm{C}_{7} \mathrm{H}_{17} \mathrm{EuO}_{11}$ : C 19.58, H 3.99\%; found: C 19.32, H $3.92 \%$.

2.1.2. [Eu(mta) $\left.\left(\mathrm{H}_{2} \mathrm{O}\right)\right]_{n} \cdot n \mathrm{H}_{2} \mathrm{O}$ (II) and (III). An aqueous solution of methanetriacetic acid $(0.1 \mathrm{M}, 10 \mathrm{ml})$ was poured
Table 3

Hydrogen-bond geometry $\left(\AA,^{\circ}\right)$ for (I), (II) and (III).

\begin{tabular}{|c|c|c|c|c|}
\hline$D-\mathrm{H} \cdots A$ & $D-\mathrm{H}$ & $\mathrm{H} \cdots A$ & $D \cdots A$ & $D-\mathrm{H} \cdots A$ \\
\hline \multicolumn{5}{|l|}{ (I) } \\
\hline $\mathrm{O} 1 W-\mathrm{H} 1 W \cdots \mathrm{O} 2^{\mathrm{i}}$ & 0.85 & 1.87 & $2.714(4)$ & 172 \\
\hline $\mathrm{O} 1 W-\mathrm{H} 2 W \cdots \mathrm{O} 4$ & 0.85 & 2.30 & $3.024(4)$ & 141 \\
\hline $\mathrm{O} 2 W-\mathrm{H} 3 W \cdots \mathrm{O} 1 W^{v}$ & 0.85 & 2.17 & $2.901(4)$ & 144 \\
\hline $\mathrm{O} 2 W-\mathrm{H} 4 W \cdots \mathrm{O} 4 W^{\mathrm{ii}}$ & 0.85 & 1.99 & $2.824(4)$ & 168 \\
\hline $\mathrm{O} 3 W-\mathrm{H} 5 W \cdots \mathrm{O} 5 W^{\mathrm{vi}}$ & 0.85 & 1.91 & $2.747(4)$ & 166 \\
\hline $\mathrm{O} 3 W-\mathrm{H} 6 W \cdots \mathrm{O} 5 W^{\mathrm{ii}}$ & 0.85 & 1.96 & $2.797(4)$ & 169 \\
\hline $\mathrm{O} 4 W-\mathrm{H} 7 W \cdots \mathrm{O} 6$ & 0.85 & 2.04 & $2.877(4)$ & 169 \\
\hline $\mathrm{O} 4 W-\mathrm{H} 8 W \cdots \mathrm{O} 4^{\mathrm{vii}}$ & 0.85 & 2.02 & $2.869(4)$ & 177 \\
\hline $\mathrm{O} 5 W-\mathrm{H} 9 W \cdots \mathrm{O} 4$ & 0.85 & 1.88 & $2.717(4)$ & 170 \\
\hline $\mathrm{O} 5 W-\mathrm{H} 10 W \cdots \mathrm{O} 4 W^{\text {viii }}$ & 0.85 & 1.93 & $2.765(4)$ & 166 \\
\hline \multicolumn{5}{|l|}{ (II) } \\
\hline $\mathrm{O} 1 W-\mathrm{H} 1 W \cdots \mathrm{O} 4^{\mathrm{vii}}$ & 0.85 & 1.98 & $2.833(10)$ & 177 \\
\hline $\mathrm{O} 1 W-\mathrm{H} 2 W \cdots \mathrm{O} 3 W^{\mathrm{viii}}$ & 0.85 & 1.89 & $2.740(12)$ & 172 \\
\hline $\mathrm{O} 2 W-\mathrm{H} 3 W \cdots \mathrm{O} 10^{\mathrm{iii}}$ & 0.85 & 1.95 & $2.800(9)$ & 180 \\
\hline $\mathrm{O} 2 W-\mathrm{H} 4 W \cdots \mathrm{O} 4 W^{\mathrm{ix}}$ & 0.85 & 1.90 & $2.749(9)$ & 179 \\
\hline $\mathrm{O} 3 W-\mathrm{H} 5 W \cdots \mathrm{O} 6^{\mathrm{ii}}$ & 0.85 & 1.93 & $2.781(12)$ & 179 \\
\hline $\mathrm{O} 4 W-\mathrm{H} 7 W \cdots \mathrm{O}^{\mathrm{x}}$ & 0.85 & 2.03 & $2.832(9)$ & 157 \\
\hline $\mathrm{O} 4 W-\mathrm{H} 8 W \cdots \mathrm{O} 11^{\mathrm{x}}$ & 0.85 & 2.03 & $2.869(10)$ & 169 \\
\hline \multicolumn{5}{|l|}{ (III) } \\
\hline $\mathrm{O} 1 W-\mathrm{H} 1 W \cdots \mathrm{O} 3^{\mathrm{vii}}$ & 0.85 & 2.06 & $2.913(4)$ & 180 \\
\hline $\mathrm{O} 1 W-\mathrm{H} 2 W \cdots \mathrm{O} 2 W$ & 0.85 & 1.98 & $2.807(7)$ & 165 \\
\hline $\mathrm{O} 2 W-\mathrm{H} 3 W \cdots 6^{\mathrm{i}}$ & 0.85 & 1.94 & $2.794(7)$ & 180 \\
\hline
\end{tabular}

Symmetry codes are as listed in Table 1. Additional symmetry codes for (I): (v) $-x-1,-y+2,-z$; (vi) $x, y, z-1$; (vii) $x+1, y-1, z$; (viii) $-x,-y+1,-z+1$. Additional symmetry codes for (II): (vii) $-x+\frac{1}{2}, y+1, z-\frac{1}{2}$; (viii) $x+\frac{1}{2},-y, z$; (ix) $x-1, y-1, z ; \quad(\mathrm{x}) \quad x+\frac{1}{2},-y+1, z$. Additional symmetry code for (III): (vii) $-x+1, y-1,-z-\frac{1}{2}$.

into an $0.05 M(20 \mathrm{ml})$ aqueous solution of $\mathrm{Eu}\left(\mathrm{NO}_{3}\right)_{3} \cdot 6 \mathrm{H}_{2} \mathrm{O}$. The resulting mixture was sealed into a $45 \mathrm{ml}$ stainless-steel reactor with teflon liner, and heated at either 423 (II) or $443 \mathrm{~K}$ (III) for $48 \mathrm{~h}$. After cooling, yellow cube-shaped crystals suitable for X-ray analysis were collected from the teflon liners and air dried. Yield $c a 60 \%$ for both compounds. Anal.: calc. for $\mathrm{C}_{7} \mathrm{H}_{11} \mathrm{EuO}_{8}$ : C 22.40, $\mathrm{H} 2.96 \%$; found: C $22.33, \mathrm{H}$ $2.86 \%$ for (II); C $22.28, \mathrm{H} 2.89 \%$ for (III).

\subsection{X-ray data collection and refinement}

Single crystals of (I), (II) and (III) were mounted on a Nonius Kappa CCD diffractometer and diffraction data were collected at $293 \mathrm{~K}$ using graphite-monochromated Mo $K \alpha$ radiation $(\lambda=0.7107 \AA)$. Crystal data, data collection and structure refinement details are summarized in Table $1 .{ }^{\mathbf{1}}$ Selected bond lengths and angles are listed in Table 2. The $\mathrm{H}$ atoms of the $\mathrm{mta}^{3-}$ ligands were placed geometrically and refined as riding atoms. $\mathrm{H}$ atoms of the water molecules were introduced so as to create a reasonable hydrogen-bonding network (Table 3), then refined as riding on their parent $\mathrm{O}$ atoms. The positions of these $\mathrm{H}$ atoms were generally quite clear, except for one $\mathrm{H}$ atom on $\mathrm{O} 3 W$ in (II) and one $\mathrm{H}$ atom on $\mathrm{O} 2 \mathrm{~W}$ in (III), which are not listed as forming hydrogen bonds in Table 3, and whose positions are uncertain. Compound (II) crystallizes in the non-centrosymmetric space group $P c a 2_{1}$, with a refined Flack parameter [0.38 (3)] signif-

\footnotetext{
${ }^{1}$ Supporting information for this paper is available from the IUCr electronic archives (Reference: BI5013).
} 
icantly different from zero, indicating inversion twinning. Different crystals of (II) were studied by single-crystal X-ray diffraction, but all tested samples presented a non-zero Flack parameter, pointing to an intrinsic twinning problem.

\section{Results and discussion}

\section{1. $\left[\mathrm{Eu}(\mathrm{mta})\left(\mathrm{H}_{2} \mathrm{O}\right)_{3}\right]_{n} \cdot 2 n \mathrm{H}_{2} \mathrm{O}(\mathrm{I})$}

Compound (I) (Fig. 1) is isomorphous with a previously published Gd ${ }^{\mathrm{III}}$ compound (Cañadillas-Delgado et al., 2010). It presents a two-dimensional framework structure, where dinuclear $\left[\mathrm{Eu}_{2}\left(\mathrm{H}_{2} \mathrm{O}\right)_{4}\right]^{6+}$ units are bonded through $\mathrm{mta}^{3-}$ ligands to form layers parallel to (001), and these layers are stacked along the $c$ axis in an $A A$ sequence. From a topological point of view, considering the $\mathrm{Eu}^{\mathrm{III}}$ ions as single nodes, a $5-c$ uninodal net is formed, designated $\left(4^{8} 6^{2}\right)$ in Schläfi notation (Blatov, 2006). The minimum interlayer $\mathrm{Eu}^{\mathrm{III}} \cdots \mathrm{Eu}^{\mathrm{III}}$

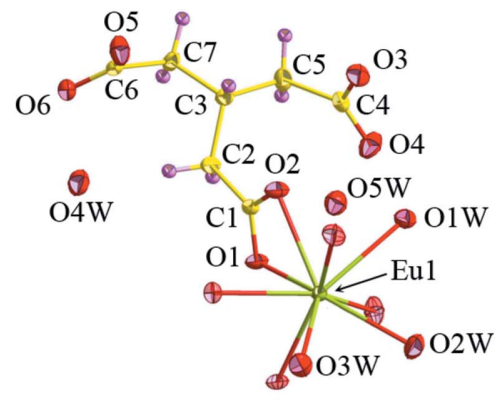

(a) (b)

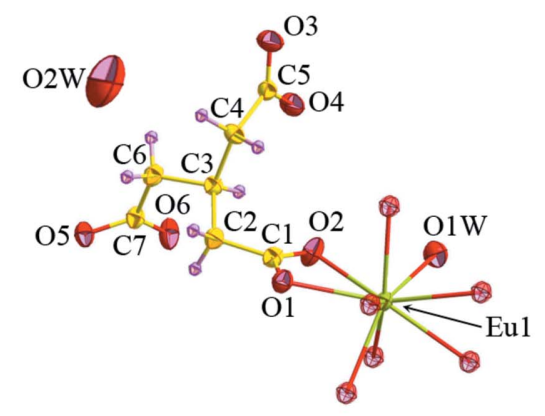

(c)

Figure 1

Asymmetric units of (I), (II) and (III) together with the coordination polyhedra for the crystallographically independent $\mathrm{Eu}^{\mathrm{III}}$ atoms (displacement ellipsoids at $50 \%$ probability). Unlabelled atoms are generated by symmetry operations.

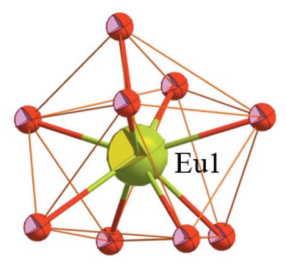

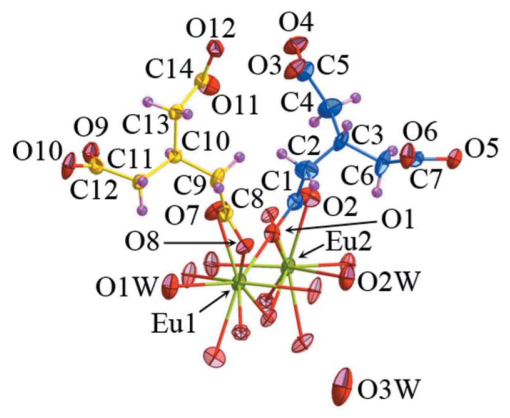

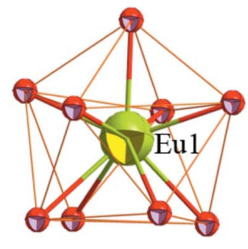

distance is 8.673 (2) $\AA$, which does not differ significantly from that reported for the isomorphous $\mathrm{Gd}^{\mathrm{III}}$ compound $[8.6750(8) \AA]$. Each $\left[\mathrm{Eu}_{2}\left(\mathrm{H}_{2} \mathrm{O}\right)_{4}\right]^{6+}$ dinuclear unit is connected to its six nearest neighbors with a shortest interdimer $\mathrm{Eu}^{\mathrm{III}} . . \mathrm{Eu}^{\mathrm{III}}$ distance of 8.0917 (13) $\AA$ (along the $a$ axis; Fig. 2). The structure includes three coordinated water molecules $(\mathrm{O} 1 W, \mathrm{O} 2 W$ and $\mathrm{O} 3 W)$ and two waters of crystal-

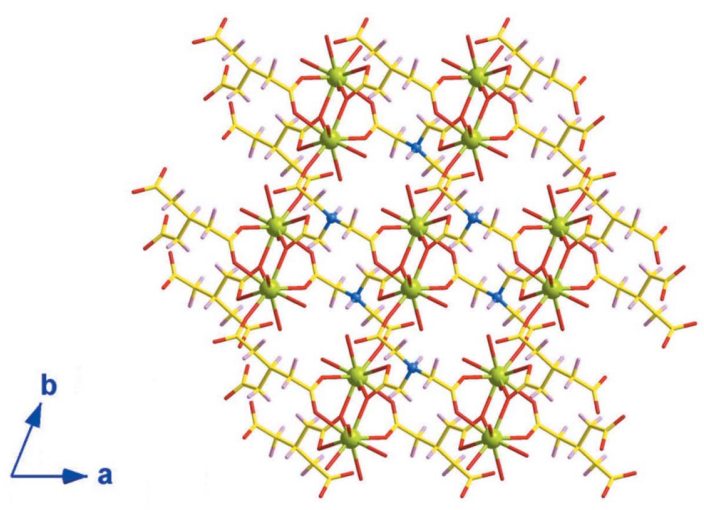

(a)

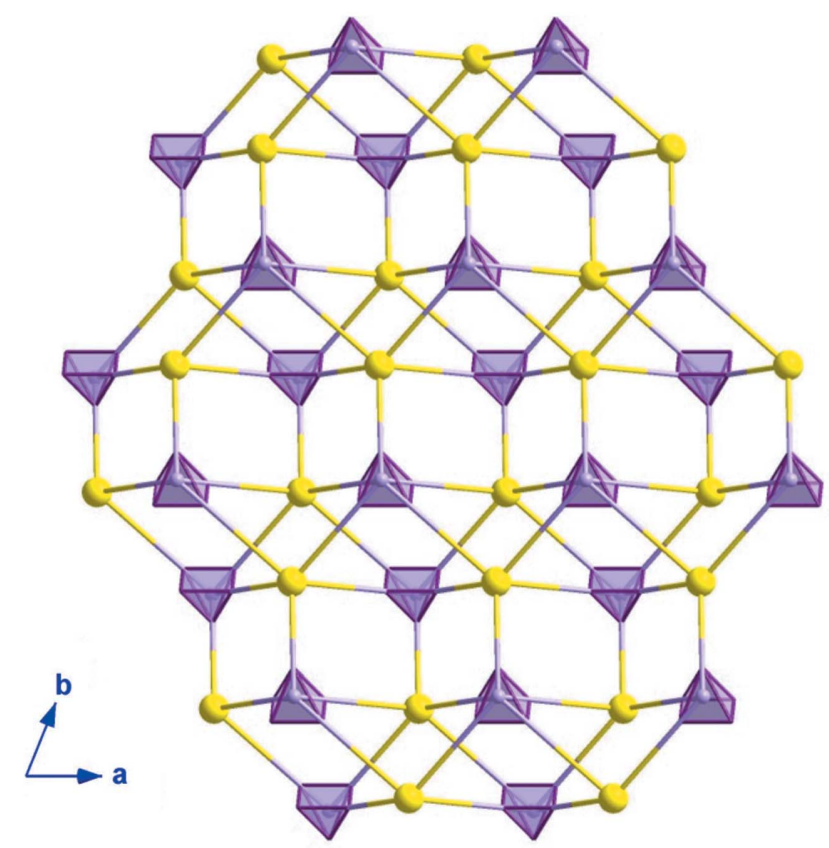

(b)

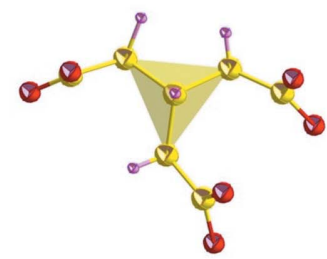

(c)
Figure 2

(a) View of the two-dimensional structure of (I) along the $c$ axis, highlighting the $\left[\mathrm{Eu}_{2}\left(\mathrm{H}_{2} \mathrm{O}\right)_{4}\right]^{6+}$ dinuclear unit connected to six neighbours through six $\mathrm{mta}^{3-}$ ligands (central $\mathrm{C}$ atom in blue); (b) topological representation of the fivefold connected $\left(4^{8} 6^{2}\right)$ uninodal network of (I), where the $\mathrm{mta}^{3-}$ ligands and $\mathrm{Eu}^{\mathrm{III}}$ atoms are represented in violet and yellow colours, respectively; $(c)$ detail of the conformation of the $\mathrm{mta}^{3-}$ ligand. 
lization $(\mathrm{O} 4 W$ and $\mathrm{O} 5 W)$, which are involved in hydrogen bonds (Table 3) that link the two-dimensional frameworks into the full three-dimensional crystal structure. If the uncoordinated water molecules are removed from the structure, there is a solvent-accessible void space of about $190 \AA^{3}$ per unit cell, which constitutes $28.5 \%$ of the total volume (Spek, 2009).

The $\mathrm{Eu}^{\mathrm{III}}$ atom is nine-coordinated, surrounded by six $\mathrm{O}$ atoms from five different $\mathrm{mta}^{3-}$ ligands $\left(\mathrm{O} 1, \mathrm{O} 2, \mathrm{O}^{\mathrm{ii}}, \mathrm{O}^{\mathrm{i}}\right.$, $\mathrm{O}^{\mathrm{iii}}, \mathrm{O}^{\mathrm{iv}}$; symmetry codes as listed in Table 2), and three water molecules $(\mathrm{O} 1 W, \mathrm{O} 2 W$ and $\mathrm{O} 3 W)$, which build a distorted monocapped square antiprism geometry with $\mathrm{Eu}-\mathrm{O}$ distances varying from 2.314 (2) to 2.565 (2) $\AA$ (Fig. 1 and Table 2). The $\mathrm{mta}^{3-}$ ligand presents bidentate (through $\mathrm{O} 1$ and $\mathrm{O} 2$ towards Eu1) and tetrakis-monodentate coordination modes [through O1, O3, O6 and O5 towards Eu $1^{\mathrm{i}}, \mathrm{Eu} 1^{\mathrm{ii}}, \mathrm{Eu} 1^{\mathrm{iv}}$ and $\mathrm{Eu} 1^{\mathrm{ix}}$, respectively; symmetry code: (ix) $\left.x+1, y, z\right]$, linking three $\left[\mathrm{Eu}_{2}\left(\mathrm{H}_{2} \mathrm{O}\right)_{4}\right]^{6+}$ units within the (001) plane (Fig. 2). Each $\left[\mathrm{Eu}_{2}\left(\mathrm{H}_{2} \mathrm{O}\right)_{4}\right]^{6+}$ dinuclear unit occupies an inversion centre. The separation Eu1 $\cdots$ Eu $1^{i i}$ and the angle at the oxobridge, Eu1-O1-Eu1 $1^{\mathrm{ii}}$, are as indicated in Table 2.
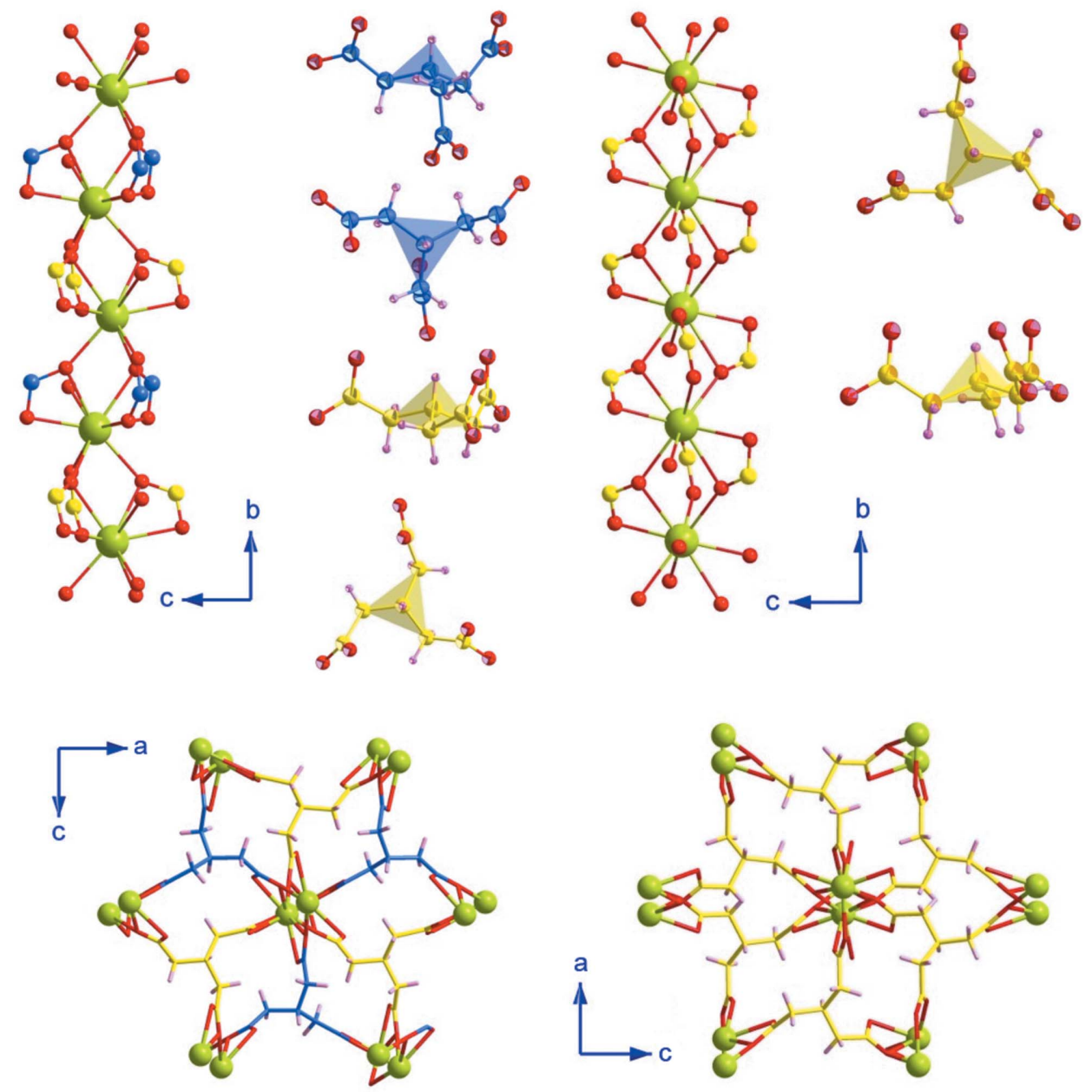

(a)

Figure 3

Crystal structures of (II) and (III), with details of the ligand conformation: (a) compound (II), with $\mathrm{mta}(1)$ coloured blue and $\mathrm{mta}(2)$ yellow; (b) compound (III). (b)

\section{2. $\left[\mathrm{Eu}(\mathrm{mta})\left(\mathrm{H}_{2} \mathrm{O}\right)\right]_{n} \cdot n \mathrm{H}_{2} \mathrm{O}$ (II)}

Compound (II) is also isomorphous with a previously reported $\mathrm{Gd}^{\mathrm{III}}$ compound (Cañadillas-Delgado et al., 2010). Its structure consists of $\left[\mathrm{Eu}\left(\mathrm{H}_{2} \mathrm{O}\right)\right]^{3+}$ units and six-connecting $\mathrm{mta}^{3-}$ ligands acting as octahedral and trigonal prismatic nodes, respectively, which result in a three-dimensional network showing the NiAs topology [a $(6,6)$-connected binodal nia-net (Blatov, 2006), with a $\left(4^{12} 6^{3}\right)\left(4^{9} 6^{6}\right)$ Schläfli symbol], which is quite rare among MOF architectures (Figs. 3 and 4; Delgado-Friedrichs et al., 2006; Wang et al., 2007; Chen et al., 2012; Bai et al., 2008; Cañadillas-Delgado et al., 2010; Chae et al., 2001; Jia et al., 2012). The structure contains chains of oxo- and syn-syn carboxylate-bridged $\mathrm{Eu}^{\mathrm{III}}$ ions running along the $b$ axis, which are interconnected through the $\mathrm{mta}^{3-}$ ligands to yield the full three-dimensional framework. Each $\mathrm{Eu}^{\mathrm{III}}$ chain is linked to its six nearest neighbours within the (010) plane with a shortest interchain separation of 7.7373 (11) $\AA$ (Eu1 ‥E Eu2 ${ }^{\text {vii }}$ : symmetry code as listed in Table 3) (Fig. 3). Four water molecules are also present in the structure, two coordinated to $\mathrm{Eu}^{\mathrm{III}}(\mathrm{O} 1 W$ and $\mathrm{O} 2 W)$ and two crystallization water molecules $(\mathrm{O} 3 W$ and $\mathrm{O} 4 W)$, which form hydrogen bonds to the carboxylate $\mathrm{O}$ atoms (Table 3). The $\mathrm{O} 3 W$ and $\mathrm{O} 4 W$ water molecules are located between the central $\mathrm{C}$ atoms of the $\mathrm{mta}^{3-}$ ligands along the $b$ axis in such a way that they fill the void space. In this case, removal of both uncoordinated water molecules leaves voids of about $160 \AA^{3}$ per unit cell, which accounts for $7.8 \%$ of the total cell volume (Spek, 2009).

Two crystallographically independent $\mathrm{Eu}^{\text {III }}$ atoms are present in (II) (Fig. 1), both being nine-coordinated with distorted monocapped square-antiprismatic environments. Eu1 is surrounded by eight $\mathrm{O}$ atoms from six $\mathrm{mta}^{3-}$ ligands $(\mathrm{O} 1$, $\mathrm{O}^{\mathrm{i}}, \mathrm{O}^{\mathrm{ii}}, \mathrm{O} 7, \mathrm{O} 8, \mathrm{O} 10^{\mathrm{iii}}, \mathrm{O} 11^{\mathrm{i}}$, O12; ; symmetry codes as listed in Table 2), and one water molecule $(\mathrm{O} 1 W)$. Atoms O1, O7, O8 and $\mathrm{O} 10^{\mathrm{iii}}$ form the base of the polyhedron, while $\mathrm{O}^{\mathrm{i}}, \mathrm{O}^{\mathrm{ii}}, \mathrm{O} 12^{\mathrm{i}}$ and $\mathrm{O} 1 \mathrm{~W}$ build the upper plane, and $\mathrm{O} 11^{\mathrm{i}}$ caps the antiprism. The mean value of the Eu1-O bond distance is $2.464 \AA$ (Table 2) and the dihedral angle between the upper and basal planes is $10.0(2)^{\circ}$. Eu2 is also surrounded by eight $\mathrm{O}$ atoms from six $\mathrm{mta}^{3-}$ ligands $\left(\mathrm{O} 1, \mathrm{O} 2, \mathrm{O}^{\mathrm{i}}\right.$, $\left.\mathrm{O}^{\mathrm{ii}}, \mathrm{O}^{\mathrm{ii}}, \mathrm{O}^{\mathrm{vi}}, \mathrm{O}^{\mathrm{iv}}, \mathrm{O}^{2} 2^{\mathrm{v}}\right)$ and one 


\section{crystal engineering}

water molecule $(\mathrm{O} 2 W)$. The basal and upper planes around Eu2 are built by atoms $\mathrm{O} 1, \mathrm{O} 2, \mathrm{O}^{1}, \mathrm{O}^{\text {vi }}$, and atoms $\mathrm{O} 5^{\mathrm{ii}}, \mathrm{O} 9^{\mathrm{iv}}$, $\mathrm{O}^{\mathrm{v}}{ }^{\mathrm{v}}, \mathrm{O} 2 \mathrm{~W}$, respectively, while atom $\mathrm{O}^{\mathrm{ii}}{ }^{\mathrm{ii}}$ caps the antiprism. The mean Eu2-O distance is $2.454 \AA$ and the dihedral angle between the basal and upper mean planes is $9.4(2)^{\circ}$.

The two crystallographically independent $\mathrm{mta}^{3-}$ ligands in (II) present both bis-bidentate/tetrakis-monodentate coordination modes. The ligand containing atom C3 [denoted mta(1), see Fig. 1] chelates Eu2 through $\mathrm{O} 1$ and $\mathrm{O} 2$ and $\mathrm{Eu} 2^{\mathrm{xi}}$ through $\mathrm{O} 5$ and O6. It also connects Eu1 to Eu2 by means of $\mathrm{O} 1, \mathrm{Eu}^{\mathrm{xi}}$ to $\mathrm{Eu} 2^{\mathrm{xi}}$ by means of $\mathrm{O}$, and $\mathrm{Eu} 1^{\mathrm{xii}}$ to $\mathrm{Eu} 2^{\mathrm{xii}}$ through the carboxylate group O3-C5-O4 [symmetry codes: (xi) $-x,-y, z+\frac{1}{2}$, (xii) $\left.-x+\frac{1}{2}, y, z+\frac{1}{2}\right]$. On the other side, the ligand containing atom $\mathrm{C} 10$ [denoted mta(2), see Fig. 1] presents a bidentate coordination mode towards Eu1 by means of $\mathrm{O} 7$ and $\mathrm{O} 8$, and to Eu1 ${ }^{\mathrm{xii}}$ through $\mathrm{O} 11$ and $\mathrm{O} 12$, and a monodentate coordination mode towards $\mathrm{Eu} 2^{\mathrm{xiii}}, \mathrm{Eu} 2^{\text {viii }}$, $\mathrm{Eu}^{\mathrm{x}}$ and $\mathrm{Eu}_{2}{ }^{\mathrm{xiv}}$ through $\mathrm{O} 8, \mathrm{O} 9, \mathrm{O} 10$ and $\mathrm{O} 12$, respectively [symmetry codes: (xiii) $x, y+1, z$; (xiv) $-x+\frac{1}{2}, y+1, z+\frac{1}{2}$ ]. Both $\mathrm{mta}^{3-}$ ligands link three $\mathrm{Eu}^{\mathrm{III}}$ chains within the (010) plane as shown in Fig. 3. The acetate arms of the $\mathrm{mta}^{3-}$ ligands present similar dihedral angles compared with those encoun- tered in the isomorphous $\mathrm{Gd}^{\mathrm{III}}$ compound (CañadillasDelgado et al., 2010). In the case of $\mathrm{mta}(1)$, these angles are $62.3(4)^{\circ}$ for $\mathrm{ac}(1) / \mathrm{ac}(2)[\mathrm{ac}(1)=\mathrm{O} 1, \mathrm{O} 2, \mathrm{C} 1, \mathrm{C} 2$; $\mathrm{ac}(2)=\mathrm{O} 3$, $\mathrm{O} 4, \mathrm{C} 4, \mathrm{C} 5], 54.5(3)^{\circ}$ for ac(1)/ac(3) $[\mathrm{ac}(3)=\mathrm{O} 5, \mathrm{O} 6, \mathrm{C} 6, \mathrm{C} 7]$ and $63.2(4)^{\circ}$ for $\mathrm{ac}(2) / \mathrm{ac}(3)$. For $\mathrm{mta}(2)$ these values are $56.1(4)^{\circ}$ for $\mathrm{ac}(4) / \mathrm{ac}(5)[\mathrm{ac}(4)=\mathrm{O} 7, \mathrm{O} 8, \mathrm{C} 8, \mathrm{C} 9 ; \mathrm{ac}(5)=\mathrm{O}$, $\mathrm{O} 10, \mathrm{C} 11, \mathrm{C} 12], 60.4(3)^{\circ}$ for $\mathrm{ac}(4) / \mathrm{ac}(6)[\mathrm{ac}(6)=\mathrm{O} 11, \mathrm{O} 12$, $\mathrm{C} 13, \mathrm{C} 14]$ and $80.3(3)^{\circ}$ for $\mathrm{ac}(5) / \mathrm{ac}(6)$.

Within the chains of $\mathrm{Eu}^{\mathrm{III}}$ ions that run along the $b$ axis, Eu1 and Eu2 alternate and are linked through two $\mu$-oxo and one carboxylate bridge. Eu1 and Eu2 are linked through $\mu$-O1; $\kappa$ $\mathrm{O} 1 \mathrm{O} 2, \mu-\mathrm{O} 5^{\mathrm{ii}} ; \kappa-\mathrm{O} 5^{\mathrm{ii}} \mathrm{O}^{\mathrm{ii}}$ and the carboxylate group $\mathrm{O} 3^{\mathrm{i}}-$

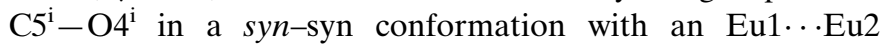
distance of 4.0767 (5) $\AA$. At the same time, Eu2 and Eu1 $1^{\mathrm{vi}}$ are linked by $\mu-\mathrm{O} 8^{\mathrm{vi}} ; \kappa-\mathrm{O} 8^{\mathrm{vi}} \mathrm{O} 7^{\mathrm{vi}}, \mu-\mathrm{O} 12^{\mathrm{v}} ; \kappa-\mathrm{O} 12^{\mathrm{v}} \mathrm{O} 11^{\mathrm{v}}$ and the carboxylate group $\mathrm{O} 9^{\text {iv }}-\mathrm{C} 12^{\text {iv }}-\mathrm{O} 10^{\text {iv }}$ in a syn-syn conformation with an Eu2 $\cdots$ Eu1 $1^{\mathrm{vi}}$ distance of 4.0767 (5) $\AA$ (Table 2).

\section{3. $\left[\mathrm{Eu}(\mathrm{mta})\left(\mathrm{H}_{2} \mathrm{O}\right)\right]_{n} \cdot n \mathrm{H}_{2} \mathrm{O}$ (III)}

Compound (III) is a new polymorph of [Eu(mta)($\left.\left.\mathrm{H}_{2} \mathrm{O}\right)\right]_{n} \cdot n \mathrm{H}_{2} \mathrm{O}$. Although it presents a similar structure to that of (II), it crystallizes in a different space group, Pbcn, which is a minimal non-isomorphic supergroup of $P c a 2_{1}$. Although there exists a group-subgroup relationship between the two structures, they are apparently not related by any structural phase transition.

The structure of (III) consists of $\left[\mathrm{Eu}\left(\mathrm{H}_{2} \mathrm{O}\right)\right]^{3+}$ units connected through six mta ${ }^{3-}$ ligands acting as octahedral and trigonal prismatic nodes, respectively, which result in a three-dimensional network that is different from (II). For (III) the network is a $(6,6)$-connected binodal $\mathrm{K}_{2} \mathrm{O}_{2}$; 36641-net (Blatov, $2006)$ with a $\left(4^{10} 6^{5}\right)\left(4^{11} 6^{4}\right)$ Schläfli symbol (Figs. 3 and 4). The threedimensional structure can be described as chains of oxo- and syn-syn carboxylate-bridged $\mathrm{Eu}^{\text {III }}$ ions running along the $b$ axis, connected along the $a$ and $c$ directions through the $\mathrm{mta}^{3-}$ ligands, with a shortest interchain separation notably shorter than that in (II) $\left[\mathrm{Eu} 1 \cdots \mathrm{Eu} 1^{\mathrm{viii}}=6.7524\right.$ (1) $\AA$; symmetry code: (viii) $x,-y+1$, $\left.-z+\frac{1}{2}\right]$. There is one coordinated $(\mathrm{O} 1 W)$ and one crystallization water molecule $(\mathrm{O} 2 W)$ that together with the carboxylate $\mathrm{O}$ atoms form hydrogen bonds (Table 3). The $\mathrm{O} 2 W$ water molecule is located
Figure 4

Topological views of the crystal structures of (a) compound (II) and (b) compound (III), with the Eu ${ }^{\text {III }}$ atoms and $\mathrm{mta}^{3-}$ ligands represented in yellow and magenta colours, respectively. The main differences in topology are enlarged. 
between two adjacent $\mathrm{mta}^{3-}$ ligands along the $b$ direction, near to the central $\mathrm{C}$ atoms, in such a way that it fills the void space. Removal of the uncoordinated water molecule leaves voids of $159.7 \AA^{3}$ per unit cell, which accounts for $7.8 \%$ of the total cell volume (Spek, 2009), noticeably less than that in (II). This reduction in the potential void space (and increase in crystal density; Table 1) is consistent with the increase of temperature in the hydrothermal synthesis, which increases the autogenous pressure inside the reactor.

Only one crystallographically independent $\mathrm{Eu}^{\mathrm{III}}$ atom is present in (III) (Fig. 1), which is nine-coordinated with a distorted monocapped square antiprismatic environment. It is surrounded by eight $\mathrm{O}$ atoms from six $\mathrm{mta}^{3-}$ ligands $\left(\mathrm{O} 1, \mathrm{O}^{\mathrm{v}}\right.$, $\mathrm{O} 2, \mathrm{O}^{3 i}, \mathrm{O}^{\mathrm{i}}, \mathrm{O}^{\mathrm{iii}}, \mathrm{O}^{\mathrm{iv}}$ and $\mathrm{O}^{\mathrm{iv}}$; symmetry codes as in Table 2) and one water molecule $(\mathrm{O} 1 W)$. Atoms $\mathrm{O} 1, \mathrm{O}^{\mathrm{v}}, \mathrm{O} 2$ and $\mathrm{O} 3^{\mathrm{ii}}$ form the base of the polyhedron, while $\mathrm{O} 4^{\mathrm{i}}, \mathrm{O}^{\mathrm{iii}}, \mathrm{O}^{\mathrm{iv}}$ and $\mathrm{O} 1 \mathrm{~W}$ build the upper plane, and $\mathrm{O}^{\mathrm{iv}}$ caps the antiprism. The mean value of the Eu1-O bond distance is $2.461 \AA$, and the dihedral angle between the upper and basal planes is $6.0(7)^{\circ}$ (Table 2).

One crystallographically independent $\mathrm{mta}^{3-}$ ligand is present in (III) (Fig. 1), with the bis-bidentate/tetrakismonodentate coordination mode, which links three $\mathrm{Eu}^{\text {III }}$ chains within the $a c$ plane, as in (II). The ligand chelates Eu1 (through $\mathrm{O} 1$ and $\mathrm{O} 2$ ) and $\mathrm{Eu} 1^{\mathrm{ix}}$ (through $\mathrm{O} 5$ and O6), and connects Eu1 $1^{\mathrm{x}}$ to Eu1 (by means of O1), Eu1 ${ }^{\mathrm{ix}}$ to Eu1 $1^{\mathrm{iii}}$ (by means of O5), and $\mathrm{Eu} 1^{\mathrm{xi}}$ to $\mathrm{Eu} 1^{\text {viii }}$ [through the carboxylate link O3-C5-O4; symmetry codes: (ix) $-x+1, y, z-\frac{1}{2}$; (x) $x+\frac{1}{2},-y+\frac{3}{2}, z$; (xi) $\left.x+\frac{1}{2}, y-\frac{1}{2},-z+\frac{1}{2}\right]$. The acetate arms of the $\mathrm{mta}^{3-}$ ligand present dihedral angles of $81.8(1)^{\circ}[\mathrm{ac}(1) /$ ac(2)] [ac(1): O1,O2,C1,C2; ac(2): O3,O4,C4,C5], $66.3(1)^{\circ}$ [ac(1)/ac(3)] [ac(3): O5, O6, C6,C7] and $45.5(1)^{\circ}[\operatorname{ac}(2) / \mathrm{ac}(3)]$.

The $\mathrm{Eu}^{\mathrm{III}}$ chain runs along the $b$ axis with the $\mathrm{Eu}^{\mathrm{III}}$ ions linked through two $\mu$-oxo and one carboxylate bridge. Atoms $\mathrm{Eu} 1$ and $\mathrm{Eu} 1^{x}$ are linked through $\mu$-O1; $\kappa$-O1O2, $\mu$-O5 $5^{\mathrm{xii}} ; \kappa-$ $\mathrm{O}^{\mathrm{xii}}{ }^{\mathrm{xii}}$ [symmetry code: (xii) $\left.-x+\frac{3}{2},-y+\frac{3}{2}, z+\frac{1}{2}\right]$ and the carboxylate group $\mathrm{O} 3^{\text {viii }}-\mathrm{C}^{\text {viii }}-\mathrm{O} 4^{\text {viii }}$ in syn-syn conformation with a Eu1 $\cdots$ Eu1 $^{x}$ distance of 4.0897 (1) $\AA$ (see Table 2).

\subsection{Comparison of the structures}

There are several features in the crystal structure of (III) that are quite similar to that of (II), including the topological description, although the Schläfli notation reveals differences between the two structures. That is, each ligand in (II) is connected to six $\mathrm{Eu}^{\mathrm{III}}$ ions that also are bonded among them through $13 \mathrm{mta}^{3-}$ ligands. In (III), however, each ligand is connected to six $\mathrm{Eu}^{\mathrm{III}}$ ions which are connected among them through only $10 \mathrm{mta}^{3-}$ ligands (see Fig. 4).

The $\mathrm{mta}^{3-}$ ligand adopts different coordination modes in (I) (bidentate/tetrakis-monodentate), (II) and (III) (bis-bidentate/tetrakis-monodentate), but also the ligand conformation differs in all of them (Fig. 5). There are three different conformations of the ligand where the carboxylate branches $\left(\mathrm{CH}_{2}-\mathrm{COO}\right)$ rotate around the single bond with the central $\mathrm{C}$ atom (see Figs. 2 and 3). The first one, present in (I), disposes the three carboxylate branches out of the plane formed by the three $\mathrm{C}$ atoms bonded to the central one [distances from plane 0.595 (4), 0.632 (4) and 0.680 (5) $\AA$ for C1, C4 and C6, respectively], pointing to the same direction as the central $\mathrm{H}$ atom. Moreover, looking along the centre $\mathrm{C}-\mathrm{H}$ bond, two of these branches rotate in a counter-clockwise sense while the third one rotates in a clockwise sense. It should be noted that the rotation senses change under the application of the inversion centre present in (I) [torsion angles: $-48.6(2)^{\circ}$ for $\mathrm{H} 3-\mathrm{C} 3-\mathrm{C} 2-\mathrm{C} 1 ; 49.9(2)^{\circ}$ for $\mathrm{H} 3-\mathrm{C} 3-\mathrm{C} 5-\mathrm{C} 4$ and $-51.3(2)^{\circ}$ for $\left.\mathrm{H} 3-\mathrm{C} 3-\mathrm{C} 7-\mathrm{C} 6\right]$. The second ligand conformation, observed in (II) and (III), again places all three branches out of the plane formed by the three $\mathrm{C}$ atoms bonded to the central one, with all carboxylate branches pointing to the same direction as the central $\mathrm{H}$ atom [distances from the plane 0.783 (7), 0.630 (6) and 0.709 (8) $\AA$ for $\mathrm{C} 8, \mathrm{C} 12$ and $\mathrm{C} 14$, in (II), respectively, and 0.634 (4), 0.941 (3) and 0.696 (3) for $\mathrm{C} 1, \mathrm{C} 5$ and $\mathrm{C} 7$, in (III), respectively]. Looking along the central $\mathrm{C}-\mathrm{H}$ bond, all three branches rotate in the same sense [torsion angles: $-40.8(8)^{\circ}$ for $\mathrm{H} 10-\mathrm{C} 10-\mathrm{C} 9-\mathrm{C} 8$; $-51.4(8)^{\circ}$ for $\mathrm{H} 10-\mathrm{C} 10-\mathrm{C} 11-\mathrm{C} 12$ and $-45.3(8)^{\circ}$ for $\mathrm{H} 10-\mathrm{C} 10-\mathrm{C} 13-\mathrm{C} 14$, in compound (II); and $50.9(3)^{\circ}$ for $\mathrm{H} 3-\mathrm{C} 3-\mathrm{C} 2-\mathrm{C} 1 ; 26.7(4)^{\circ}$ for $\mathrm{H} 3-\mathrm{C} 3-\mathrm{C} 4-\mathrm{C} 5$ and $47.2(4)^{\circ}$ for $\mathrm{H} 3-\mathrm{C} 3-\mathrm{C} 6-\mathrm{C} 7$, in compound (III)]. Even though (II) crystallizes in a non-centrosymmetric space group, the application of the mirror symmetry contained in the $a c$ and $b c$ planes gives rise to the occurrence of both ligand rotation senses within the crystal structure. The same feature occurs in (III), where $\mathrm{mta}^{3-}$ ligands with the carboxylate arms rotated in both senses are present due to the occurrence of an inversion centre. The third conformation is present only in (II), where two of the carboxylate branches point towards the central H atom [distances from plane 0.838 (8) and 1.137 (7) $\AA$ for $\mathrm{C} 5$ and $\mathrm{C} 7$, respectively], one of them rotating in a clockwise sense and the other one in a counter-clockwise sense [torsion angles: $-37.1(10)^{\circ}$ for $\mathrm{H} 3-\mathrm{C} 3-\mathrm{C} 4-\mathrm{C} 5$ and $7.4(9)^{\circ}$ for $\mathrm{H} 3-\mathrm{C} 3-\mathrm{C} 6-\mathrm{C} 7]$. The third carboxylate branch points in the opposite direction [distance from plane 1.485 (8) $\AA$ for C1] and stays almost parallel to the central $\mathrm{C}-\mathrm{H}$ bond [torsion angle: $-172.9(7)^{\circ}$ for $\mathrm{H} 3-\mathrm{C} 3-\mathrm{C} 2-\mathrm{C} 1$ ].

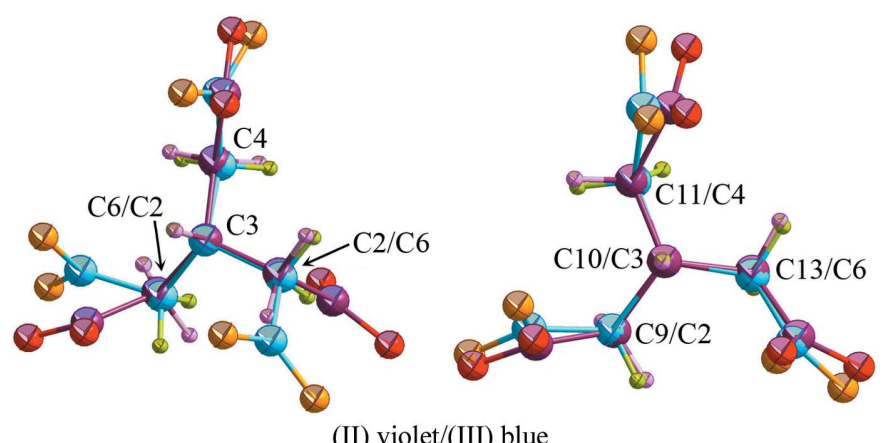

Figure 5

(II) violet/(III) blue

View of the superposition of the $\mathrm{mta}^{3-}$ ligands present in (II) and (III), where the $\mathrm{mta}^{3-}$ in (II) is represented with $\mathrm{C}, \mathrm{O}$ and $\mathrm{H}$ atoms in violet, red and pink, respectively, while the $\mathrm{mta}^{3-}$ ligand in (III) is depicted with $\mathrm{C}, \mathrm{O}$ and $\mathrm{H}$ atoms in blue, orange and green, respectively. 


\section{crystal engineering}

\section{Conclusions}

The first $\mathrm{Eu}^{\mathrm{III}}$-containing methanetriacetate compounds have been synthesized, through gel [for (I)] and hydrothermal methods [for (II) and (III)]. Two of them, (I) and (II), are isomorphous with two $\mathrm{Gd}^{\mathrm{III}}$ compounds reported previously (Cañadillas-Delgado et al., 2010), where the main differences arise from the lanthanide contraction. Compound (III) represents a new polymorph. Compounds (II) and (III) crystallize in space groups $P b c n$ and $P c a 2_{1}$, respectively. Although there exists a group-subgroup relation between them, the compounds are not related by a phase transition, although their crystal structures show significant similarities. Both polymorphs were obtained through hydrothermal conditions, although at different synthetic temperatures, and consequently autogenous pressures. An increase in temperature produced not only the different topology [nia-net in (II) and $\mathbf{K}_{2} \mathbf{O}_{2} ; 36641$-net in (III)], but also a reduction in the unit-cell volume (an increase in density) and in the available space for solvent molecules [ 7.8 and $5 \%$ of the total unit-cell volume for (II) and (III), respectively]. Additionally, it can be seen that hydrothermal synthesis in general favours high-dimensional compact architectures, since compound (I) presents a twodimensional arrangement, while compounds (II) and (III) are three-dimensional framework structures with small solventaccessible space.

The $\mathrm{mta}^{3-}$ ligand adopts two different coordination modes in (I) (bidentate/tetrakis-monodentate), (II) and (III) (bisbidentate/tetrakis-monodentate), but also its conformation differs in all of them. There are three different conformations of the ligand, where the acetate branches rotate around the single bond with the central $\mathrm{C}$ atom. These different conformations and coordination modes adopted by the $\mathrm{mta}^{3-}$ anion demonstrate the flexibility of the ligand.

In summary, the combination of flexible tripodal ligands with lanthanide ions opens a huge number of possibilities for construction of MOFs, within the crystal engineering field. For that reason, full understanding of the different coordination modes and conformations of a given ligand is mandatory to obtain smart materials with tailored properties. The construction of further novel architectures based on lanthanide ions with different ionic radii is in progress, together with investigations of the applications of these materials in luminescent systems.

This work was partly funded through projects MAT201016981, MAT2011-27233-C02-02, DPI2010-2103-C04-03 and the Consolider-Ingenio projects CSD2007-00010, and CSD2006-00015 'La Factoría' and CTQ2007-61690 from the Spanish MICINN, as well as through the Agencia Canaria de Investigación, Innovación y Sociedad de la Información (ACIISI) through project PIL-2070901. JP acknowledges the Consolider CSD2006-00015 project for a post-doctoral contract.

\section{References}

Bai, Y. L., Tao, J., Huang, R. B., Zheng, L. S., Zheng, S. L., Oshida, K. \& Einaga, Y. (2008). Chem. Commun. pp. 1753-1755.
Baumeister, J. M., Alberto, R., Ortner, K., Spingler, B., Schubiger, P. A. \& Kaden, T. A. (2002). J. Chem. Soc. Dalton Trans. pp. $4143-$ 4151.

Blatov, V. A. (2006). IUCr Compcomm Newsl. 7, 4-38.

Brandenburg, K. (1999). DIAMOND. Crystal Impact GbR, Bonn, Germany.

Byrappa, K. \& Yoshimura, M. (2001). Handbook of Hydrothermal Technology: Technology for Crystal Growth and Materials Processing. New York: William Andrew Inc.

Cañadillas-Delgado, L., Fabelo, O., Pasán, J., Delgado, F. S., Déniz, M., Sepúlveda, E., Laz, M., Julve, M. \& Ruiz-Pérez, C. (2008). Cryst. Growth Des. 8, 1313-1318.

Cañadillas-Delgado, L., Fabelo, O., Rodríguez-Velamazán, J. A., Lemée-Cailleau, M. H., Mason, S. A., Pardo, E., Lloret, F., Zhao, J. P., Bu, X. H., Simonet, V., Colin, C. V. \& Rodríguez-Carvajal, J. (2012). J. Am. Chem. Soc. 134, 19772-19781.

Cañadillas-Delgado, L., Martín, T., Fabelo, O., Pasán, J., Delgado, F. S., Lloret, F., Julve, M. \& Ruiz-Pérez, C. (2010). Chem. Eur. J. 16, 4037-4047.

Chae, H. K., Eddaoudi, M., Kim, J., Hauck, S. I., Hartwig, J. F., O'Keeffe, M. \& Yaghi, O. M. (2001). J. Am. Chem. Soc. 123, 1148211483.

Chen, M., Wang, C., Hu, M. \& Liu, C. (2012). Inorg. Chem. Commun. 17, 104-107.

Chen, B., Yang, Y., Zapata, F., Lin, G., Qian, G. \& Lobkovsky, E. B. (2007). Adv. Mater. 19, 1693-1696.

Delgado-Friedrichs, O., O'Keeffe, M. \& Yaghi, O. M. (2006). Acta Cryst. A62, 350-355.

Duisenberg, A. J. M., Kroon-Batenburg, L. M. J. \& Schreurs, A. M. M. (2003). J. Appl. Cryst. 36, 220-229.

Dwiggins, C. W. (1975). Acta Cryst. A31, 146-148.

Farha, O. K., Yazaydin, A. O, Eryazici, I., Malliakas, C. D., Hauser, B. G., Kanatzidis, M. G., Nguyen, S. T., Snurr, R. Q. \& Hupp, J. T. (2010). Nat. Chem. 2, 944-948.

Farrugia, L. J. (1999). J. Appl. Cryst. 32, 837-838.

Furukawa, H., Cordova, K. E., O'Keeffe, M. \& Yaghi, O. M. (2013). Science, 341, 123044.

Gao, X. D., Zhu, G. S., Li, Z. Y., Sun, F. X., Yang, Z. H. \& Qiu, S. L. (2006). Chem. Commun. pp. 3172-3174.

Gupta, K. A., Saxena, A. K., Jain, P. C. \& Anand, N. (1987). Indian J. Chem. Sect. B, 26, 341-343.

Gustafsson, M., Li, Z., Zhu, G., Qiu, S., Grins, J. \& Zou, X. (2008). Stud. Surf. Sci. Catal. 174, 451-454.

Henisch, H. K. (1970). Crystal Growth in Gels. Pittsburg: The Pennsylvania State Univ. Press.

Jia, J., Sun, F., Borjigin, T., Ren, H., Zhang, T., Bian, Z., Gao, L. \& Zhu, G. (2012). Chem. Commun. 48, 6010-6012.

Kitagawa, S., Kitaura, R. \& Noro, S. (2004). Angew. Chem. Int. Ed. 43, 2334-2375.

Lee, J., Farha, O. K., Roberts, J., Scheidt, K. A., Nguyen, S. T. \& Hupp, J. T. (2009). Chem. Soc. Rev. 38, 1450-1459.

Li, X. B., Zhang, J. Y., Wang, Y. Q., Song, Y. \& Gao, E. Q. (2011). Chem. Eur. J. 17, 13883-13891.

Nardelli, M. (1995). J. Appl. Cryst. 28, 659.

Nonius (1998). COLLECT. Nonius BV, Delft, The Netherlands.

Otwinowski, Z. \& Minor, W. (1997). Methods in Enzymology, Vol. 276, Macromolecular Crystallography, Part A, edited by C. W. Carter Jr \& R. M. Sweet, pp. 307-326. New York: Academic Press.

Rosi, N. L., Kim, J., Eddaoudi, M., Chen, B., O'Keeffe, M. \& Yaghi, O. M. (2005). J. Am. Chem. Soc. 127, 1504-1518.

Sheldrick, G. M. (2008). Acta Cryst. A64, 112-122.

Spek, A. L. (2009). Acta Cryst. D65, 148-155.

Sumida, K., Rogow, D. L., Mason, J. A., McDonald, T. M., Bloch, E. D., Herm, Z. R., Bae, T. H. \& Long, J. R. (2012). Chem. Rev. 112, 724-781.

Tian, Y. Q., Zhao, Y. M., Chen, Z. X., Zhang, G. N., Weng, L. H. \& Zhao, D. Y. (2007). Chem. Eur. J. 13, 4146-4154. 


\section{crystal engineering}

Wang, Z., Zhang, X., Batten, S. R., Kurmoo, M. \& Gao, S. (2007). Inorg. Chem. 46, 8439-8441.

Wang, Z., Zhang, Y., Liu, T., Kurmoo, M. \& Gao, S. (2007). $A d v$. Funct. Mater. 17, 1523-1536.
Yaghi, O. M., O'Keeffe, M., Ockwig, N. W., Chae, H. K., Eddaoudi, M. \& Kim, J. (2003). Nature, 423, 705-714.

Zhang, X. M., Wang, Y. Q., Song, Y. \& Gao, E. Q. (2011). Inorg. Chem. 50, 7284-7294. 